\title{
STATE OF THYMUS COENOPOPULATIONS IN THE SOUTHERN SIBERIA ${ }^{1}$
}

\section{E. B. Talovskaya}

Central Siberian Botanical Garden, Siberian Branch of the Russian Academy of Sciences, 101 Zolotodolinskaya street, Novosibirsk, 630090, Russia

E-mail: kolegova_e@mail.ru

\section{A. Cheryomushkina}

Central Siberian Botanical Garden, Siberian Branch of the Russian Academy of Sciences, 101 Zolotodolinskaya street, Novosibirsk, 630090, Russia

E-mail:kolegova_e@mail.ru

\section{СОСТОЯНИЕ ЦЕНОПОПУЛЯЦИЙ ВИАОВ РОАА THYMUS НА ЮГЕ СИБИРИ}

\section{Е. Б. Таловская}

Центральный сибирский ботанический сад Сибирского отделения Российской академии наук, Россия, 63009о, г. Новосибирск, ул. Золотодолинская, 101

E-mail: kolegova_e@mail.ru

\section{В. А. Черемушкина}

Центральный сибирский ботанический сад Сибирского отделения Российской академии наук, Россия, 63009о, г. Новосибирск, ул. Золотодолинская, 101

E-mail: kolegova_e@mail.ru

Abstract. Background. The study of species coenopopulations and their stability in a particular area is a necessary stage when searching for ways of rational use of natural resources. The species of the genus Thymus in the southern Siberia is widely distributed. This species is found in the communities of mountain and lowland steppes, forest steppes and forests. The objective of this work is to explore the ontogenetic structure of Thymus coenopopulations in the southern Siberia and estimate the current state of this species. Materials and methods. Using the conventional methods particular features of life forms have been studied and biomorphs of 15 species of thyme have been selected; 22 coenopopulations of 10 species, which are distinguished by biomorph and the extent of distribution, have been investigated. Results. This research has shown that in the southern Siberia the species of the genus Thymus is formed in six life forms (vegetative-immotile form for the shrub and semi-shrub, vegetative-semi-motile form for the shrub and semi- shrub, vegetative-motile form for the shrub and semi- shrub) and three types of biomorphs (monocentric vegetative-immotile biomorph, implicitly polycentric vegetative-semimotile biomorph, explicitly polycentric vegetative-motile biomorph). A relation between biological features of the species and the type of characteristic ontogenetic spectrum has been shown. Biological specific features of implicitly and explicitly polycentric species identify the left-sided type of the characteristic spectrum, of monocentric species, the type of spectrum is determined as centered one. The difference between the majority of ontogenetic spectra of specific coenopopulations from the typical spectrum is due to polyvariety of species development (alteration of the biomorph in the same species, a change in the prevailing propagation direction, reduction in the duration (or absence) of the generative period) and characteristics of the arranged ecotope system. Conclusions. For the thymes of different biomorphs the factors of habitats and specific features which influence the stable state of their coenopopulation are identified. It has been ascertained that Thymus coenopopulations in the southern Siberia are in a stable state or tend to be in this state. A comparative analysis of the data obtained made it possible to put forward some patterns of population behavior of thymes which can be extrapolated into another species of the genus Thymus with similar types of biomorphs.

Key words: coenopopulation, ontogenetic structure, biomorph, ontogenesis, Thymus, southern Siberia.

For citation: Talovskaya E.B., Cheryomushkina V.A. State of thymus coenopopulations in the southern Siberia. Russian Journal of Ecosystem Ecology. 2017;2(3). Available from: https://doi.org/10.21685/2500-0578-2017-3-4

Аннотация. Актуальность и цели. Изучение ценопопуляций видов и их устойчивости на конкретной территории является необходимым этапом в решении проблем рационального природопользования. Виды рода Thymus на юге Сибири имеют широкое распространение. Они встречаются в сообществах горных и рав-

${ }^{1}$ Исследование выполнено при финансовой поддержке РФФИ в рамках научного проекта 15-04-02857-а и проекта государственного задания № 0312-2016-0003. 
нинных степей, лесостепей и лесов. Цель работы - изучение онтогенетической структуры ценопопуляций видов рода Thymus на юге Сибири и оценка их современного состояния. Материалы и методы. По общепринятым методикам изучены особенности жизненной формы и выделены биоморфы 15 видов тимьянов; проведено исследование 22 ценопопуляций 10 видов, отличающихся типом биоморфы и широким распрораспространением. Результаты. Установлено, что в условиях юга Сибири у видов рода Thymus формируется 6 жизненных форм (вегетативно-неподвижный кустарничек и полукустарничек, вегетативно-полуподвижный кустарничек и полукустарничек, вегетативно-подвижный кустарничек и полукустарничек) и три типа биоморф (моноцентрическая вегетативно-неподвижная, неявнополицентрическая вегетативно-полуподвижная, явнополицентрическая вегетативно-подвижная). Выявлена связь биологических особенностей видов и типа характерного онтогенетического спектра. Биологические особенности неявнополицентрических и явнополицентрических видов определяют левосторонний тип характерного спектра, моноцентрических - центрированный. Отличие большинства онтогенетических спектров конкретных ценопопуляций от характерного типа связано с поливариантностью развития особей (изменение биоморфы у одного и того же вида, смена преобладающего способа размножения, сокращение длительности (или пропуск) генеративного периода) и особенностями экотопа. Выводы. Аля тимьянов разных биоморф выделены факторы среды обитания и признаки, влияющие на устойчивое состояние их цП. Установлено, что ценопопуляции видов рода Thymus на юге Сибири находятся в устойчивом состоянии или приближаются к нему. Сравнительный анализ полученных данных позволил выделить некоторые варианты популяционного поведения тимьянов, которые можно экстраполировать на другие виды рода Thymus со сходными типами биоморф.

Ключевые слова: ценопопуляция, онтогенетическая структура, биоморфа, онтогенез, Thymus, юг Сибири.

The search for ways of rational use of natural resources has become more relevant in recent times. Both Russian and foreign authors agree that a solution to this task is possible with a comprehensive study of natural ecosystems, predicting their development and plans for recovery [1-6]. The solution of a number of tasks in this direction can be found if using the concept of the population organization of ecosystems, one of the approaches of this concept is the study of species coenopopulations and their stability in a particular area $[7,8]$.

The species of the genus Thymus L. are widely distributed virtually throughout Eurasia. But the greatest expansion of thyme can be seen on the territory of Siberia. As E. E. Gogina notes [9], it is related to the diversity of mountain systems, vegetation and the substrate. Thyme habitats in the southern Siberia are associated mainly with the communities of mountain and lowland steppes, forest-steppes and forests. Typical habitats for the most species are petrophytous grassland communities of the middle or upper parts of rubble slopes and aligned hill tops. Total projective cover degree of thyme in the grass cover reaches $60 \%$, species abundance is about 40 species [10]. In the aligned areas and in the lower parts of the slopes the species are included in the composition of shrubsteppe communities with high projective coverage of up to $70 \%$. In the sandy steppes along the slopes of dunes and hillocks, wind eroded cloughs, deflation surfaces thymes form communities with a small participation of such species as Festuca rubra ssp. baicalensis, Agropyron distichum (Fisch.ex Link) Schult., Bromopsis inermis (Leyss.) Holub [11, 12]. The species of the genus Thymus do not participate in the initial stages of the overgrowing of sands, but populate already stabilized areas with a thinned grass stand and a total projective coverage of up to $10 \%$ [13]. In the steppes thymus persists for a long time in the terms of grazing, but gradually the state of their populations deteriorates until they disappear completely [14]. Often thymes are found in ruderal communities near the shelter, together with Panzerina lanata (L.) Sojak, Plantago media L., Urtica dioica L, etc. [15]. Some species of thymes (T. mongolicus (Ronn.) Ronn., T. jenisseensis Iljin etc.) ascend to the alpine belt. They are included in the composition of petrophytous variants of meadows along stony outcrops of mountain ridges, and also in the composition of alpine meadows in flatland areas [16].

The aim of the work is to study the ontogenetic structure of the coenopopulations of species of the genus Thymus in southern Siberia and to assess their current state.

\section{Materials and methods}

About 15 species of the genus Thymus are listed for the territory of the southern Siberia [17]. On the basis of I. G. Serebryakov's ecologicalmorphological classification [18] the life form of each species is described. In accordance with O. V. Smirnova's phytocenotic classification [19] the thymes have monocentric, implicitly polycentric and polycentric biomorphs. In order to explore the ontogenetic structure of coenopopulations (CP) ten species with different biomorphs and widely distributed in the study area have been selected. They are: T. altaicus Klok. et Schost., T. baicalensis Serg., T. elegans Serg., T. iljinii Klok. et Schost., T. jenisseensis, T. krylovii Byczennikova, T. minussinensis Serg., T. mongolicus, T. proximus Serg., T. sibiricus (Serg.) Klok. et Schost. 22 coenopopulations (CP) were investigated. The brief characteristics of their location is given in Table 1. Ontogenesis of the individuals of the species is described according to the concept of a descrete ap- 
proach to the description of higher plant ontogeny proposed by T. A. Rabotnov [20] and A. A. Uranov [21]. More than 10,000 herbarium samples of the thymes were analyzed. The ontogenetic structure of the $\mathrm{CP}$ was studied by common methods [20-22]. Transects $1 \mathrm{~m}$ in width and $5-10 \mathrm{~m}$ in length were laid out and divided into trial sites (small plots) of $1 \mathrm{~m}^{2}$. The universal enumeration of the individuals of species was performed for each ontogenetic state. The individuals of seed origin and a compact clone were taken as a calculation unit for the species of monocentric biomorph; the individuals derived from seeds, particule and individuals of seed origin, partial tufts were used as calculation units for implicitly polycentric biomorph and explicitly polycentric biomorph, respectively. The ontogenetic spectrum of the $\mathrm{CP}$ was determined as a ratio of plants of different ontogeny states expressed as a percentage of the total number of individuals. A characteristic ontogenetic type of the $\mathrm{CP}$ spectrum is established by the concept of L. B. Zaugolnova [23]. Ecological density of the $\mathrm{CP}$ is estimated during calculation of individual sizes per unit of the occupied location [24].

Characteristic of Thymus site

\begin{tabular}{|c|c|c|c|c|c|c|}
\hline Species & $\begin{array}{l}\text { Number of coe- } \\
\text { nopopulation }\end{array}$ & $\begin{array}{c}\text { Location of coenopopula- } \\
\text { tion }\end{array}$ & $\begin{array}{c}\text { Community/dominant } \\
\text { species }\end{array}$ & Substrate & $\begin{array}{c}\mathrm{TPCD} \\
\%\end{array}$ & $\begin{array}{l}\text { PCD, } \\
\%\end{array}$ \\
\hline 1 & 2 & 3 & 4 & 5 & 6 & 7 \\
\hline \multirow[t]{5}{*}{ T. baicalensis } & 1 & $\begin{array}{l}\text { Lake Baikal, Olkhon } \\
\text { island, Semisosensky } \\
\text { Bay, Todakte Cape, } \\
h=714 \text { m above sea level }\end{array}$ & $\begin{array}{l}\text { Thyme-feather-grass true } \\
\text { petrophytous steppe / } \\
\text { Stipa baicalensis Roshev, } \\
\text { S. pennata L., } \\
\text { T. baicalensis, } \\
\text { Agropyron cristatum (L.) } \\
\text { Gaertner, Potentilla } \\
\text { acaulis L. }\end{array}$ & $\begin{array}{l}\text { Fine earth } \\
\text { with crushed } \\
\text { stone }\end{array}$ & 60 & 5 \\
\hline & 2 & $\begin{array}{l}\text { Irkutsk region, } \\
\text { surroundings of Sarma } \\
\text { village, Small Sea coast, } \\
\text { shoots of the Primorye } \\
\text { mountains, } \\
\text { South East hillside, } \\
\text { middle part, slope angle } \\
30^{\circ}, h=714 \text { m above sea } \\
\text { level }\end{array}$ & $\begin{array}{l}\text { Fescue-sedge true } \\
\text { petrophytous steppe / } \\
\text { Carex pediformis } \\
\text { C. A. Mey., Festuca } \\
\text { lenensis Drobow, } \\
\text { Koeleria cristata }(\text { L.) } \\
\text { Pers., Artemisia frigida } \\
\text { Willd., Potentilla acaulis }\end{array}$ & $\begin{array}{l}\text { Fine earth } \\
\text { with crushed } \\
\text { stone }\end{array}$ & 60 & 3 \\
\hline & 3 & $\begin{array}{l}\text { Lake Baikal, Olkhon } \\
\text { island, Semisosensky } \\
\text { Bay, Semisosensky } \\
\text { Sandy Massif, deflation } \\
\text { plain, } h=715 \mathrm{~m} \text { above } \\
\text { sea level }\end{array}$ & $\begin{array}{l}\text { Thyme-leymus sandy } \\
\text { steppe/Leymus chinensis } \\
\text { (Trin.) Tzvelev, } \\
\text { T. baicalensis, Festuca } \\
\text { ruba L., Bromopsis } \\
\text { inermis (Leysser) Holub, } \\
\text { Carex sabulosa Turcz. } \\
\text { ex Kunth. }\end{array}$ & Sand & 70 & 10 \\
\hline & 4 & \begin{tabular}{|l} 
Lake Baikal, Olkhon \\
island, Khuzhir Bay, \\
Khuzhiry Sandy Massif, \\
deflation plain, $h=713 \mathrm{~m}$ \\
above sea level
\end{tabular} & $\begin{array}{l}\text { Sedge-oxytrope-thyme } \\
\text { sandy steppe / } \\
\text { T. baicalensis, Carex } \\
\text { ericetorum Pollich, } \\
\text { Oxytropis lanata (Pall.) } \\
\text { DC., Agropyron } \\
\text { distichum (Georgi) } \\
\text { Peschkova, Bromopsis } \\
\text { inermis }\end{array}$ & Sand & 50 & 15 \\
\hline & 5 & $\begin{array}{l}\text { Tuva, Uvs-Nuur Hollow, } \\
\text { blowing wind pit, flat } \\
\text { plot, } h=1193 \text { m above } \\
\text { sea level }\end{array}$ & \begin{tabular}{|l|} 
Thyme sandy steppe / \\
T. baicalensis Agropyron \\
desertorum (Fisch. ex \\
Link) Schult., Artemisia \\
tomentella Trautv., \\
Oxytropis \\
tragacanthoides Fisch., \\
Gypsophila patrinii Ser.
\end{tabular} & Sand & 25 & 12 \\
\hline
\end{tabular}


Continuation of Table 1

\begin{tabular}{|c|c|c|c|c|c|c|}
\hline 1 & 2 & 3 & 4 & 5 & 6 & 7 \\
\hline T. altaicus & 6 & $\begin{array}{l}\text { Republic of Khakassia, } \\
\text { Ust-Abakan district, } \\
\text { Beika village, plain, } \\
h=574 \text { m above sea level }\end{array}$ & $\begin{array}{l}\text { Herb-fescue-thyme true } \\
\text { steppe / T. altaicus, } \\
\text { Festuca valesiaca } \\
\text { (Hask.) Gaudin, } \\
\text { Artemisia frigida, } \\
\text { Galium verum L., } \\
\text { Aster alpinus L. } \\
\end{array}$ & Fine earth & 80 & 10 \\
\hline T. elegans & 7 & $\begin{array}{l}\text { Republic of Khakassia, } \\
\text { suburbs of Beisk district, } \\
\text { Tabat village, mountain } \\
\text { area «Menzhilai», } \\
\text { southwestern hillslope, } \\
\text { near to the top, slope } \\
\text { angle } 20^{\circ}, h=619 \mathrm{~m} \\
\text { above sea level }\end{array}$ & $\begin{array}{l}\text { Birch-spruce-larch forest } \\
\text { / Larix sibirica Ledeb., } \\
\text { Pinus sylvestris L., } \\
\text { Betula rotundifolia } \\
\text { Spach, Phleum phleoides } \\
\text { (L.) H. Karst., Poa } \\
\text { pretensis L., Festuca } \\
\text { airoides Lam., Carex } \\
\text { pediformis, Dianthus } \\
\text { versicolor Fisch. ex Link }\end{array}$ & $\begin{array}{l}\text { Black } \\
\text { earth soil }\end{array}$ & 60 & 3 \\
\hline T. iljinii & 8 & $\begin{array}{l}\text { Republic of Khakassia, } \\
\text { Bogdarsk district, } \\
\text { surroungings of } \\
\text { Pervomayskoe village, } \\
\text { upper part of the north } \\
\text { hillslope, slope angle } 35^{\circ} \text {, } \\
h=301 \mathrm{~m} \text { above sea level }\end{array}$ & $\begin{array}{l}\text { Sedge- } \\
\text { feather-grass true steppe / } \\
\text { Stipa capillata L., Stipa } \\
\text { krylovii Roshev., Carex } \\
\text { duriuscula } \text { C.A. Mey, } \\
\text { T. iljinii, Alyssum lenense } \\
\text { Adams, Gypsophila } \\
\text { patrinii }\end{array}$ & $\begin{array}{l}\text { Fine earth } \\
\text { with pebble }\end{array}$ & 55 & 5 \\
\hline \multirow[t]{4}{*}{ T. jenisseensis } & 9 & $\begin{array}{l}\text { Krasnoyarsky Krai, } \\
\text { Shushenskoye district, } \\
\text { surroundings of Sizaya } \\
\text { village, bank of the } \\
\text { Yenisei river, } h=306 \mathrm{~m} \\
\text { above sea level }\end{array}$ & $\begin{array}{l}\text { Herb-meadow steppe / } \\
\text { Achillea asiatica Serg., } \\
\text { Veronica longifolia L., } \\
\text { T. jenisseensis, } \\
\text { Helictotrichon } \\
\text { desertorum (Less.) } \\
\text { Nevski, Poa annua L. }\end{array}$ & $\begin{array}{l}\text { Sand among } \\
\text { big crushed } \\
\text { stones }\end{array}$ & 80 & 10 \\
\hline & 10 & $\begin{array}{l}\text { Krasnoyarsky Krai, } \\
\text { Kurgan region, } \\
\text { surroundings of } \\
\text { Cheremshanka village, } \\
\text { cobble bank of the river } \\
\text { Kazyr, } h=374 \text { m above } \\
\text { sea level }\end{array}$ & $\begin{array}{l}\text { Thyme vegetation zone } \\
\text { on gravel / } T \text {. } \\
\text { jenisseensis, Elytrigia } \\
\text { repens }(L) \text { Nevski, } \\
\text { Galium verum, Trifolium } \\
\text { repens L., Potentilla } \\
\text { bifurca L. }\end{array}$ & $\begin{array}{l}\text { Sand with } \\
\text { gravel }\end{array}$ & 15 & 3 \\
\hline & 11 & $\begin{array}{l}\text { Tuva, Piy Khemsky } \\
\text { District, Ujuk Range, the } \\
\text { Arzak river valley, top of } \\
\text { the hillslope, slope angle } \\
20^{\circ}, h=1001 \mathrm{~m} \text { above } \\
\text { sea level }\end{array}$ & $\begin{array}{l}\text { Shrubby forb-meadow } \\
\text { petrophytous steppe/ } \\
\text { Caragana pygmaea (L.) } \\
\text { DC., Carex pediformis, } \\
\text { Elytrigia gmelinii (Trin.) } \\
\text { Nevski, Allium senescens } \\
\text { L., Pulsatilla } \\
\text { turczaninovii } \\
\text { Krylov \& Serg. }\end{array}$ & $\begin{array}{l}\text { Fine earth } \\
\text { with crushed } \\
\text { stone }\end{array}$ & 40 & 2 \\
\hline & 12 & $\begin{array}{l}\text { The Altai Republic, } \\
\text { Shebalino region, } \\
\text { Cherginsky Range, } \\
\text { surroundungs of Moguta } \\
\text { village, Moguta river } \\
\text { valley, middle part of the } \\
\text { southern hillslope, slope } \\
\text { angle } 35^{\circ}, h=701 \mathrm{~m} \\
\text { above sea level }\end{array}$ & $\begin{array}{l}\text { Shrubby helictotrichon - } \\
\text { firm-bruch grass } \\
\text { petrophytous steppe / } \\
\text { Caragana pygmaea, } \\
\text { Spiraea chamaedryfolia L., } \\
\text { Helictotrichon } \\
\text { desertorum, Carex } \\
\text { pediformis, Artemisia } \\
\text { gmelinii Weber ex } \\
\text { Stechm. }\end{array}$ & $\begin{array}{l}\text { Fine earth } \\
\text { with crushed } \\
\text { stone }\end{array}$ & 55 & 1 \\
\hline
\end{tabular}


Continuation of Table 1

\begin{tabular}{|c|c|c|c|c|c|c|}
\hline 1 & 2 & 3 & 4 & 5 & 6 & 7 \\
\hline & 13 & $\begin{array}{l}\text { Tuva, Mongun- } \\
\text { Tayginsky District the } \\
\text { Tzagan-Shibetu mountain } \\
\text { range, the Barlyk river } \\
\text { valley, cobble of the } \\
\text { temporary river bed, } \\
\text { rarely flooded, } \\
h=2084 \mathrm{~m} \text { above sea } \\
\text { level }\end{array}$ & $\begin{array}{l}\text { Wormwood-thyme } \\
\text { community in the cobble } \\
\text { of the temporary river } \\
\text { bed / Artemisia } \\
\text { santolinifolia Turcz. ex } \\
\text { Besser, T. jenisseensis, } \\
\text { Poa attenuata Trinius, } \\
\text { Stipa krylovii, Galium } \\
\text { verum }\end{array}$ & $\begin{array}{l}\text { Sand with } \\
\text { fine pebble }\end{array}$ & 27 & 12 \\
\hline \multirow[t]{3}{*}{ T. mongolicus } & 14 & $\begin{array}{l}\text { Tuva, surroundings of } \\
\text { Cherbi village, the } \\
\text { Terektig-Khem river } \\
\text { valley, back bank, } h= \\
981 \mathrm{~m} \text { above sea level }\end{array}$ & $\begin{array}{l}\text { Shrubby silky } \\
\text { wormwood-feather-grass } \\
\text { true petrophytous steppe / } \\
\text { Caragana pygmaea, } \\
\text { Stipa orientalis Trin., } \\
\text { Artemisia frigida, } \\
\text { Elytrigia gmelinii, Carex } \\
\text { supina Willd. ex } \\
\text { Wahlenb. }\end{array}$ & $\begin{array}{l}\text { Fine earth } \\
\text { with crushed } \\
\text { stone }\end{array}$ & 35 & 2 \\
\hline & 15 & $\begin{array}{l}\text { Tuva, sands of Central } \\
\text { Tuva basin, lower part of } \\
\text { the blowing wind boiler, } \\
\text { slope angle } 4^{\circ}, h=764 \mathrm{~m} \\
\text { above sea level }\end{array}$ & $\begin{array}{l}\text { Shrubby thyme sandy } \\
\text { steppe / Caragana } \\
\text { pygmaea, T. mongolicus, } \\
\text { Agropyron cristatum, } \\
\text { Artemisia globosa } \\
\text { Krasch., Stipa krylovii }\end{array}$ & Sand & 15 & 12 \\
\hline & 16 & $\begin{array}{l}\text { Tuva, the Naryn river } \\
\text { valley, southern hillslope, } \\
\text { middle part, slope angle } \\
35^{\circ}, \\
h=1900 \mathrm{~m} \text { above sea } \\
\text { level }\end{array}$ & $\begin{array}{l}\text { Shrubby helictotrichon- } \\
\text { tragacanth true } \\
\text { petrophytic steppe / } \\
\text { Helictotrichon } \\
\text { desertorum, Oxytropis } \\
\text { tragacantoides, Carex } \\
\text { pediformis, Artemisia } \\
\text { frigida, Potentilla acaulis }\end{array}$ & $\begin{array}{l}\text { Crushed } \\
\text { stone }\end{array}$ & 55 & 3 \\
\hline T. proximus & 17 & $\begin{array}{l}\text { Republic of Khakassia, } \\
\text { Altay District, } \\
\text { surroundings of Tabat } \\
\text { village, southern steep } \\
\text { slope of the hill, middle } \\
\text { part, slope angle } 30^{\circ}, \\
h=500 \mathrm{~m} \text { above sea level }\end{array}$ & $\begin{array}{l}\text { Herb-firm-bruch grass } \\
\text { shrubby petrophytous } \\
\text { meadow steppe / } \\
\text { Caragana pygmaea, } \\
\text { Carex pediformis, } \\
\text { Chamaerhodos erecta, } \\
\text { Artemisia frigida, } \\
\text { Galium verum, Veronica } \\
\text { incana L., Androsace } \\
\text { filiformis } \text { Retz. }\end{array}$ & $\begin{array}{l}\text { Fine earth } \\
\text { with crushed } \\
\text { stone }\end{array}$ & 50 & 5 \\
\hline T. sibiricus & 18 & $\begin{array}{l}\text { Republic of Khakassia, } \\
\text { Ust-Abakan region, } \\
\text { surroundings of } \\
\text { Moskovskoye village, } \\
\text { plain, } h=435 \text { m above } \\
\text { sea level }\end{array}$ & $\begin{array}{l}\text { Grass-wormwood, } \\
\text { shrubby Caragana } \\
\text { pygmaea true steppe / } \\
\text { Artemisia frigida, } \\
\text { Artemisia commutate } \\
\text { Bess., Stipa capillata, } \\
\text { Festuca valesiaca, } \\
\text { Bupleurum multinerve } \\
\text { DC. }\end{array}$ & Sand & 70 & 5 \\
\hline T. iljinii & 19 & $\begin{array}{l}\text { Republic of Khakassia, } \\
\text { Altay District, } \\
\text { surroundings of Belyi Yar } \\
\text { village, plain, } h=335 \mathrm{~m} \\
\text { above sea level }\end{array}$ & $\begin{array}{l}\text { Feather-grass-thyme big } \\
\text { bunch sandy steppe / } \\
\text { T. iljinii, Stipa capillata, } \\
\text { Stipa krylovii, Agropyron } \\
\text { cristatum, Koeleria } \\
\text { cristata, Carex } \\
\text { duriuscula, Aster alpinus }\end{array}$ & Sand & 50 & 10 \\
\hline
\end{tabular}


End of Table 1

\begin{tabular}{|c|c|c|c|c|c|c|}
\hline 1 & 2 & 3 & 4 & 5 & 6 & 7 \\
\hline \multirow[t]{2}{*}{ T. krylovii } & 20 & $\begin{array}{l}\text { Republic of Khakassia, } \\
\text { Askiz District, } \\
\text { surroundings of Askiz } \\
\text { village, northern slope of } \\
\text { the hill, lower part, angle } \\
\text { slope } 45^{\circ}, h=365 \mathrm{~m} \\
\text { above sea level }\end{array}$ & $\begin{array}{l}\text { Herb-grass meadow } \\
\text { steppe / Calamagrostis } \\
\text { neglecta (Ehrh.) Gaerth., } \\
\text { Mey. et Scherb., Stipa } \\
\text { capillata, Cleistogenes } \\
\text { squarrosa (Trin.) Keng, } \\
\text { Galium verum, Geranium } \\
\text { pratense L. }\end{array}$ & Loam & 90 & 3 \\
\hline & 21 & $\begin{array}{l}\text { Republic of Khakassia, } \\
\text { Ust-Abakan region, } \\
\text { surroundings of } \\
\text { Moskovskoye village, } \\
\text { trench along the field } \\
\text { road, } h=405 \text { m above } \\
\text { sea level }\end{array}$ & \begin{tabular}{|l|} 
Herb-wheat grass \\
derivative plant \\
community in sandy \\
steppe / Elytrigia \\
geniculata (Trin.) \\
Nevski, Elytrigia repens, \\
Atriplex fera (L.) Bunge, \\
Artemisia commutata, \\
Galium verum, Medicago \\
falcata L., Vicia \\
cracca L. \\
\end{tabular} & Sand & 30 & 3 \\
\hline T. minussinensis & 22 & $\begin{array}{l}\text { Republic of Khakassia, } \\
\text { Altay District, } \\
\text { surroundings of Belyi Yar } \\
\text { village, plain, } h=300 \mathrm{~m} \\
\text { above sea level }\end{array}$ & \begin{tabular}{|l|} 
Big Bunchgrass-thyme \\
sandy steppe / \\
T. minussinensis, Festuca \\
valesiaca, Stipa \\
capillata, Agropyron \\
cristatum, \\
Chamaerhodos erecta \\
(L.) Bunge, Artemisia \\
frigida, Veronica incana \\
\end{tabular} & Sand & 60 & 25 \\
\hline
\end{tabular}

Note: CP is coenopopulation; TPCD is total projective cover degree of herbage; PCD is projective cover degree of the species.

\section{Results}

The study of thymes distribution in the southern Siberia showed that a wide range of ecological and cenotic growing conditions with specific features of the relief and substrate is characteristic for the spe- cies. The morphological mechanism of species adaptation to habitat was the emergence of a variety of life forms and types of ontogenesis. It has been established that three types of biomorphs are formed in species of the genus Thymus in the southern Siberia. Their brief characteristics are presented in Table 2.

Table 2

Characteristic of Thymus individuals with different biomorphs

\begin{tabular}{|l|c|c|c|}
\hline \multicolumn{1}{|c|}{ Features } & Monocentric & Implicitly polycentric & Polycentric \\
\hline Life cycle $\mathrm{g}_{2}$, year & $10-20$ & $1-2$ & $2-3$ \\
\hline $\mathrm{g}_{2}$ diameter of the individual, cm & $\begin{array}{l}15 \text { (shrub with above }- \\
\text { ground root system) } \\
150 \text { (cushion-shaped) }\end{array}$ & $20-30$ & $40-70$ \\
\hline $\begin{array}{l}\text { Distance from the primary shoot to } \\
\text { a new center of anchoring, cm }\end{array}$ & - & $1,5-15$ & $3-45$ \\
\hline $\begin{array}{l}\text { Number of particulation formations un- } \\
\text { der complete disintegration } \\
\text { of the individual, plants }\end{array}$ & - & up to 16 & up to 90 \\
\hline Onset of vegetative reproduction & - & $\mathrm{g}_{2}$ & $\mathrm{~g}_{1}(\mathrm{v})$ \\
\hline Rejuvenation of ramets & - & up to $\mathrm{g}_{1}$ & $\mathrm{up} \mathrm{to} \mathrm{im}$ \\
\hline
\end{tabular}

1. Monocentric vegetative-immobile biomorph. Typical for the shrub T. baicalensis and semishrubs T. marschallianus Willd., T. roseus Schipcz. In the petrophytous steppes at the tops of the hills, in the conditions of a lack of substrate, moisture and strong winds action, the species represent an aerial shrub; under the same conditions along the hillslopes they acquire a humistratous form [25]. In the conditions of sandy steppe on the mobile substrate $T$. baicalensis a cushion-shaped life form develops (Foto 1) [26]. 


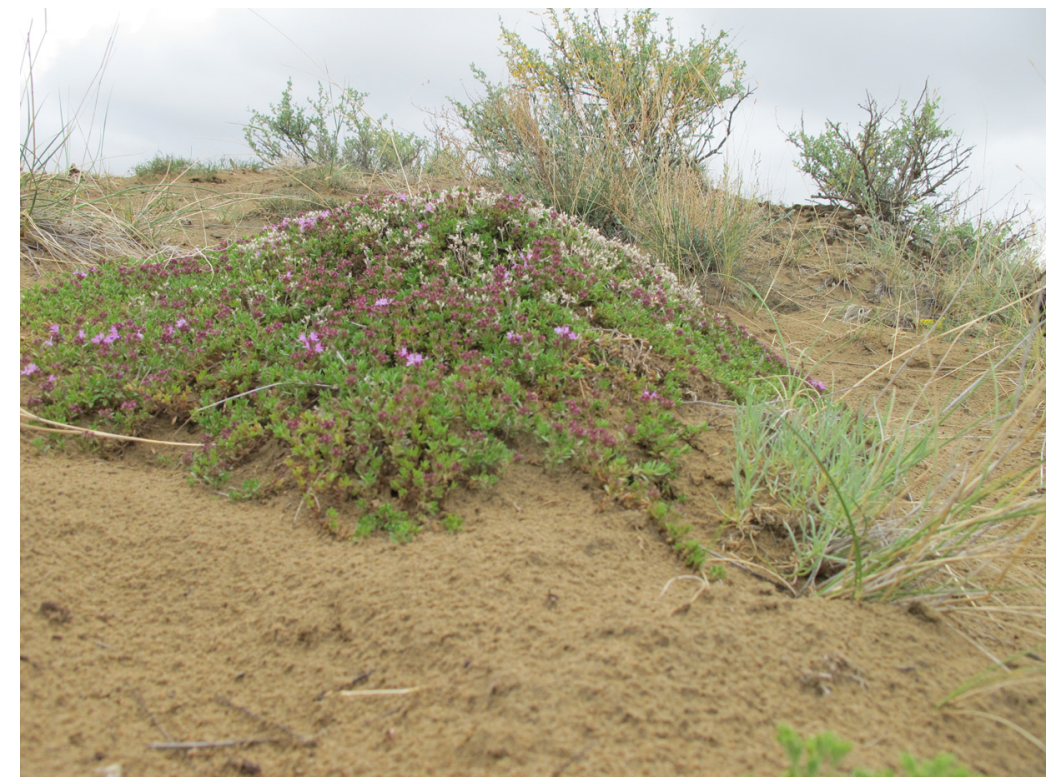

Photo 1. T. baicalensis in sandy steppe (deflationary surface)

For adult individuals of vegetative-immobile biomorphs the following is typical: preservation of the main root until the complete dying of the individual; physical connection of the primary shrub with the partial ones; weak vegetative outgrowth. Individuals ontogenesis of all species, according to L. A. Zhukova's classification [27], corresponds to ontogenesis of taproot polycarpous plants and is characterized by the duration of the generative state up to 20 years; possible senile particulation in the old generative state; self-maintenance of the coenopopulations only by the seed reproduction (Fig. 1).
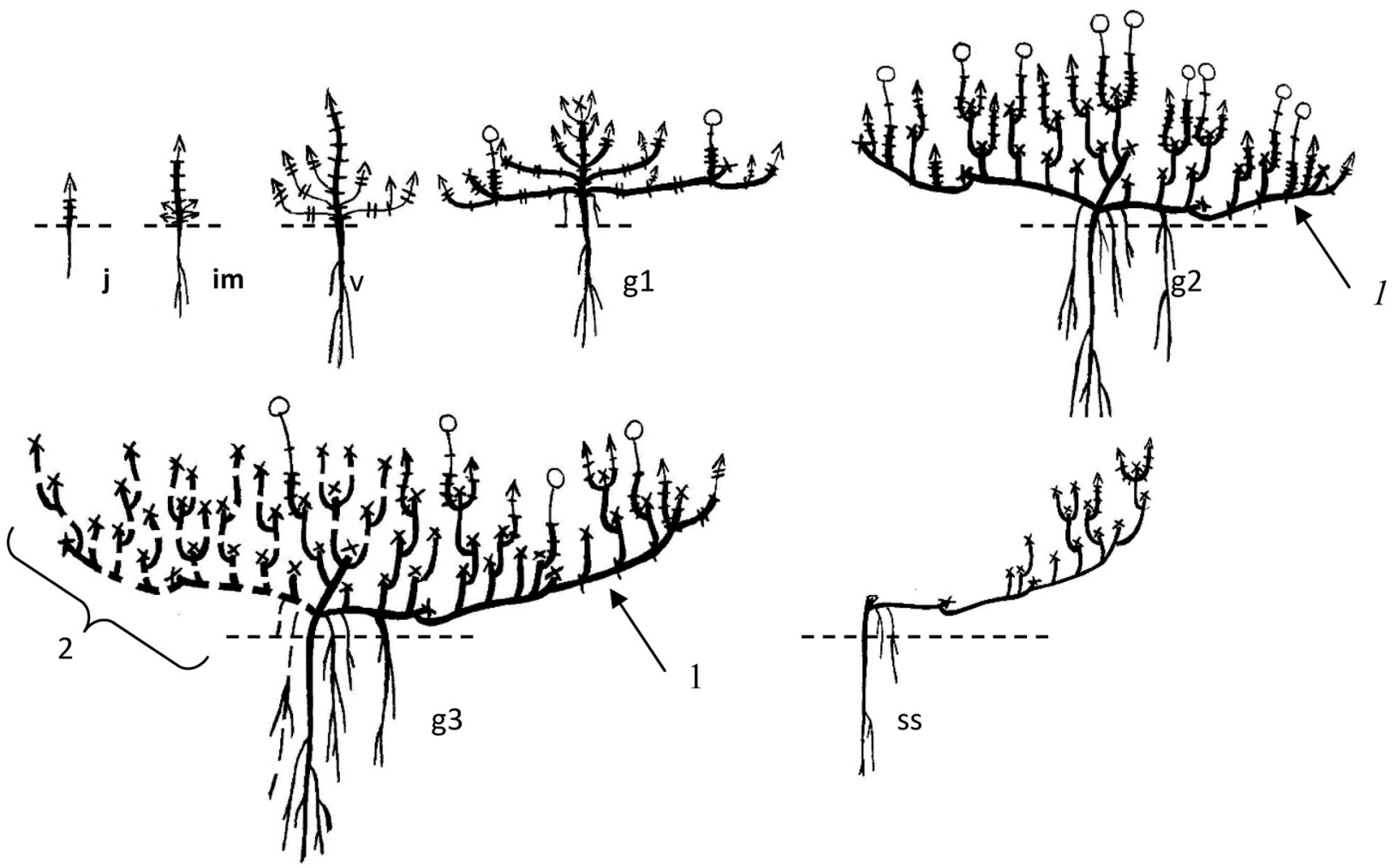

Fig. 1. Ontogenesis of the Thymus baicalensis individuals of seed origin, vegetative-immobile biomorph:

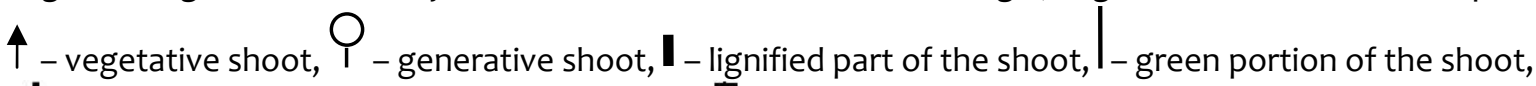

\$-approximate nodes, $\mathbf{\$}$-scattered nodes, $\boldsymbol{\xi}$-adventitious root, - _ - - soil level; 1 - composite monopodial-sympodial skeletal axis, 2 - dead portion of the shrub; ontogenetic states: j - juvenile, im - immature, v - virginile, g1 - young generative, g2 - mature generative, g3 - old generative, ss - subsenile 
2. Implicitly polycentric vegetative-semimobile biomorph. Typical for the shrubs $T$. altaicus, T. elegans, T. iljinii, T. mongolicus, T. petraeus Serg., T. proximus, T. schischkinii Serg., $T$. sibiricus and semishrubs $T$. jenisseensis, $T$. dahuricus Serg., T. roseus (Foto 2). It is formed in the mountain and plain steppes on a static substrate. For adult individuals it is typical: preservation of the main root, weak vegetative outgrowth and reproduction, slow territory expansion due to the close location of partial structures to the prima- ry shrub (no more than $15 \mathrm{~cm}$ ). The ontogenesis of individuals is complete, complex and consists of ontogenesis of the seed individual and ramets (Fig. 2). Vegetative reproduction is irregular, begins in the middle of ontogenesis with the formation of superficially rejuvenated ramets. Self-maintenance of the coenopopulation is mixed. The ontogenesis of individuals of the vegetative-semi-mobile biomorph corresponds to the ontogenesis of monopodial short-rhizomatous grass described by V. A. Cheryomushkina and T. V. Leonova [28].

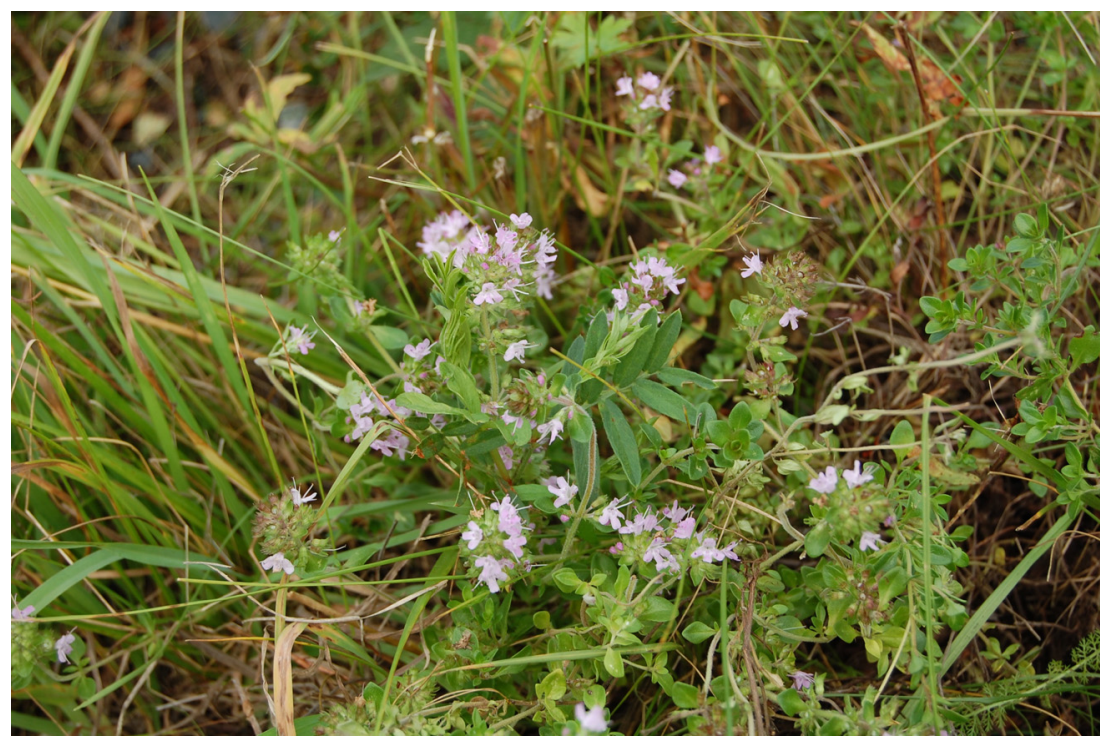

Photo 2. T. jenisseensis in meadow steppe

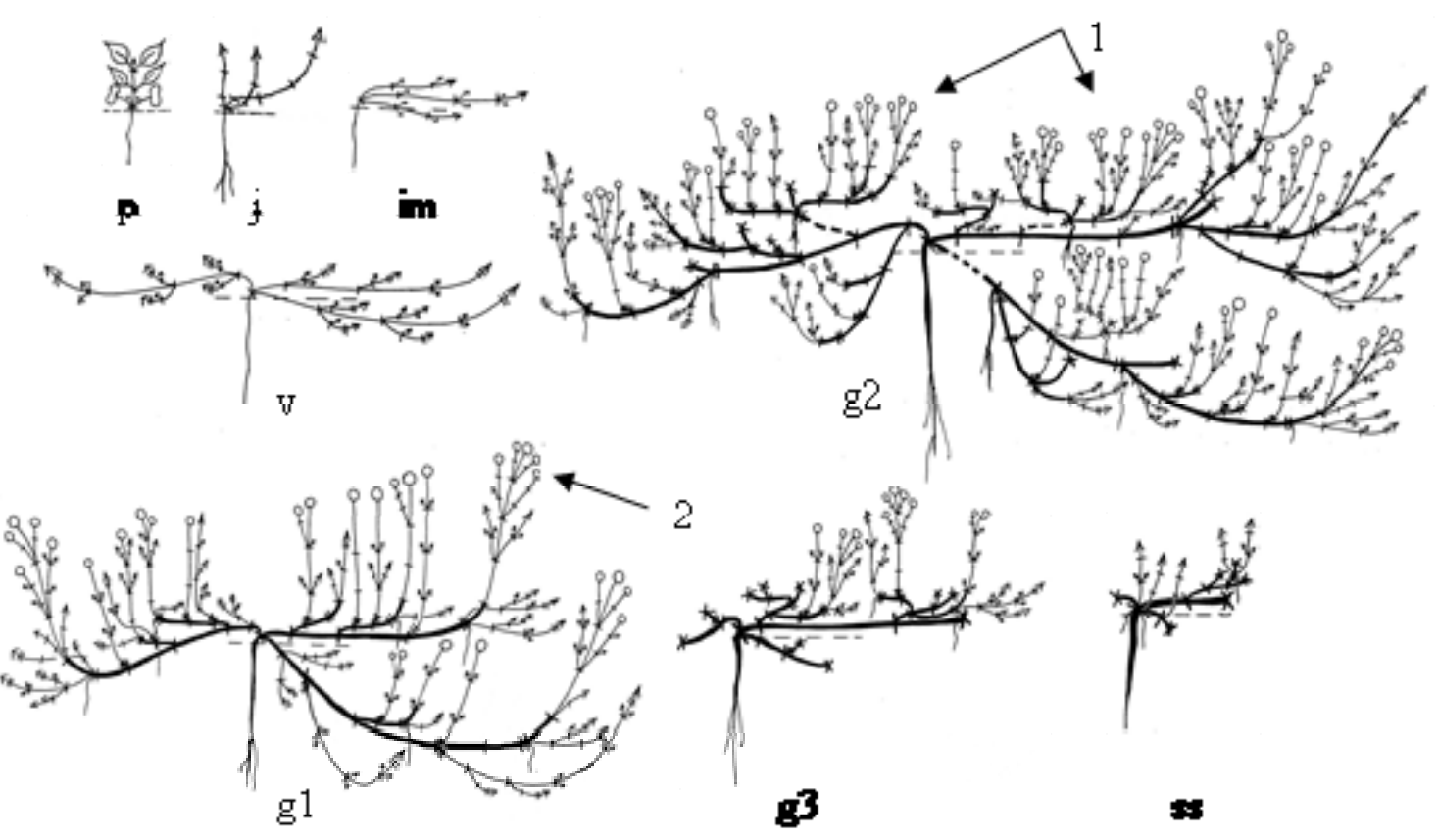

Fig. 2. Ontogenesis of the Thymus jenisseensis individuals of seed origin, vegetative-semi-mobile biomorph (1 - detached partial shrub, 2 - branched generative shoot, $p$ - sprout, the rest of the symbols are the same as in Fig. 1)

3. Explicitly polycentric vegetative-mobile biomorph. Typical for shrubs T. iljinii, T. minussinensis and semishrubs $T$. krylovii, $T$. roseus
(Photo 3). It is formed in the steppes in conditions of a flexible sandy substrate and is characterized by the main root dieback in the old generative 
state; intensive vegetative outgrowth; increase of distance between the primary shrub and the partial shrub (up to $45 \mathrm{~cm}$ ); intensive expansion of new areas of the territory. The ontogenesis of individuals is complete, complex, consists of ontogenesis of the seed individual and ramets (Fig. 3).

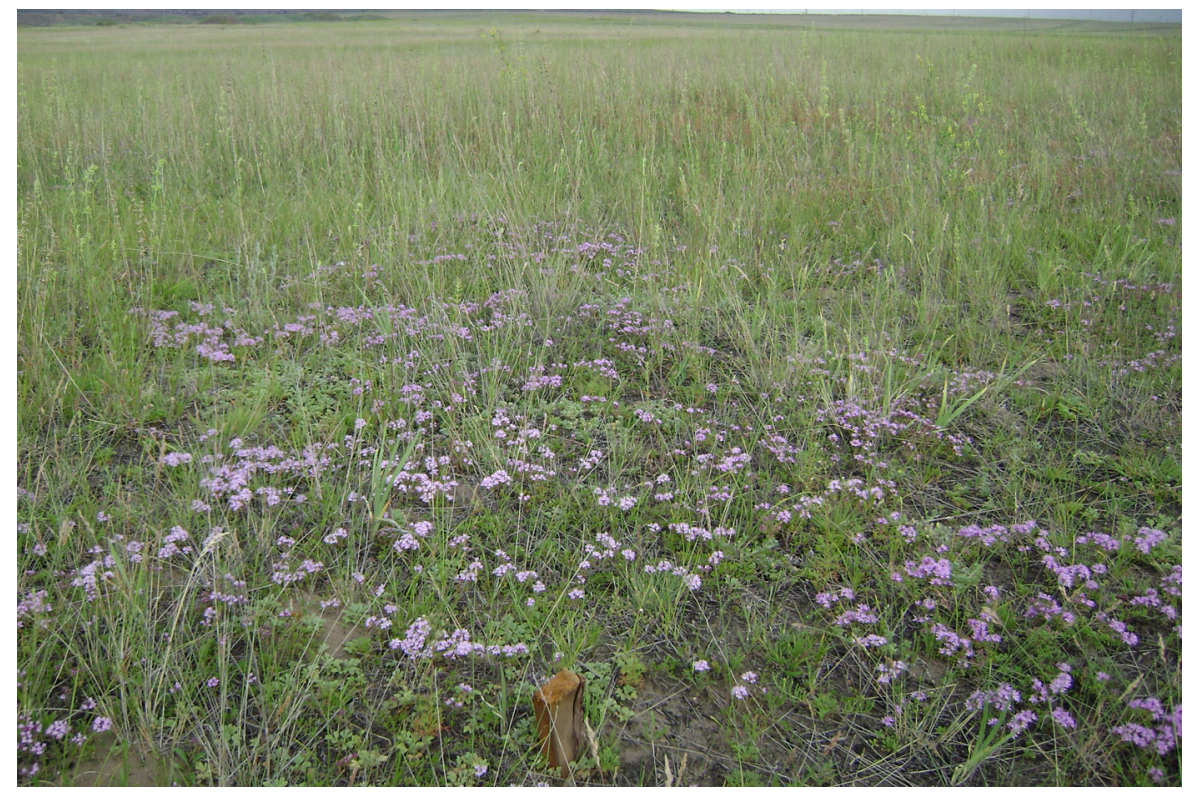

Photo 3. T. minussinensis in sandy steppe

Vegetative reproduction is regular, with the formation of deeply rejuvenated ramets. Selfmaintenance of the coenopopulation is carried out mainly vegetatively [29]. The ontogenesis of individuals corresponds to the ontogenesis of longrhizomatous plant species according to the classification of L. A. Zhukova [27].
The study of the development of ten species of thymes of different biomorphs made it possible to reveal their biological features, which determine the type of characteristic ontogenetic spectrum of coenopopulations.

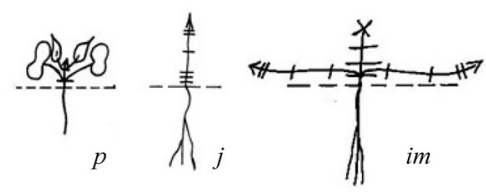

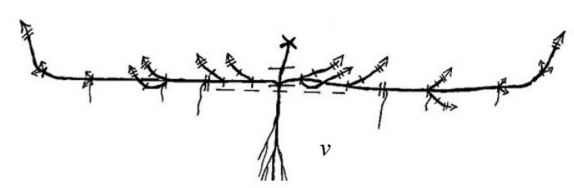
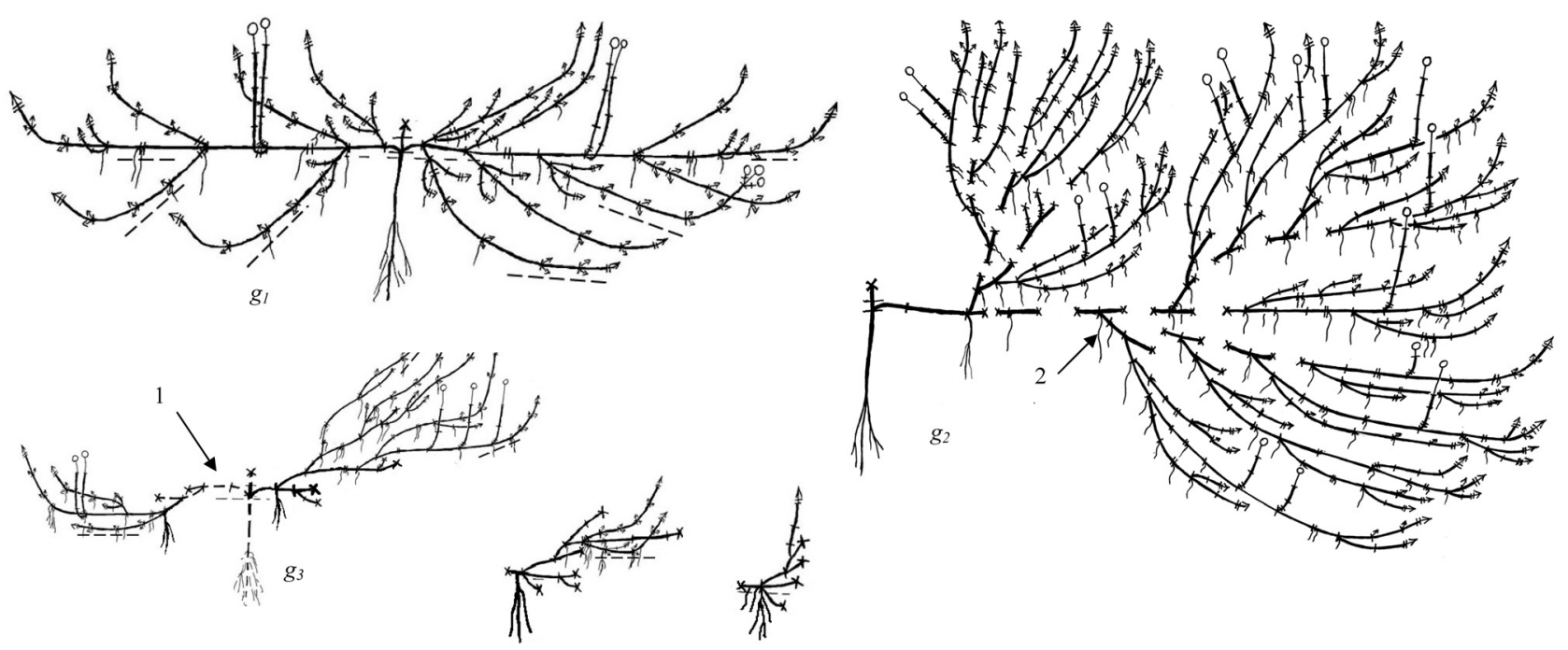

Fig. 3. Ontogenesis of the Thymus iljinii individuals of seed origin, vegetative-mobile biomorph

(1 - dying portion of the shrub and the main root, partial shrub, the portion of the individual is represented in g2, $\mathrm{s}$ is senile ontogenetic state, the rest of the symbols are the same as in Fig. 1 and Fig. 2) 
Characteristic ontogenetic spectrum of vegetative-immobile $T$. baicalensis has a centered type, it is determined by such biological signs as: a prolonged, mature generative state of individuals; only the seed method of reproduction. The explored coenopopulations of $T$. baicalensis are normal, the most are not full-membered (Table 3 ). In coenopopulations $2,4,5$ there are no individuals of juvenile, immature, senile conditions, and in coenopopulation 3 there are also no individuals of the subsenile state. In coenopopulations $2-4$ the bio- logical properties of the species appear, and as a consequence, the spectrum of specific coenopopulations coincides with the distinctive centered type. Coenopopulation 2 is located on a slope in the fescue-sedge true petrophytous steppe on a finegrained substrate. Due to the lodging and rooting of skeletal axes, individuals spread out and form solid clusters. Due to irregular seed propagation, wind erosion of seeds and undergrowth from the slope of the pregenerative fraction individuals in these clusters is insignificant.

Table 3

Distribution of the Thymus individuals by ontogenetic group and ecological density of their coenopopulation

\begin{tabular}{|c|c|c|c|c|c|c|c|c|c|c|}
\hline \multirow{2}{*}{ Species } & \multirow{2}{*}{ № CP } & \multicolumn{8}{|c|}{ Ontogenetic groups, $\%$} & \multirow{2}{*}{$P_{\text {ecol }}$} \\
\hline & & $\mathrm{j}$ & $\mathrm{im}$ & $\mathrm{v}$ & $\mathrm{g}_{1}$ & $\mathrm{~g}_{2}$ & $\mathrm{~g}_{3}$ & ss & $\mathrm{s}$ & \\
\hline \multicolumn{11}{|c|}{ Vegetative immobile biomorph } \\
\hline \multirow{5}{*}{ T. baicalensis } & 1 & 0.3 & 1.8 & 13.1 & 37.3 & 33.5 & 8.3 & 5.4 & 0.3 & 37.3 \\
\hline & 2 & - & - & 9.5 & 26.6 & 39.9 & 15.8 & 8.2 & - & 10.2 \\
\hline & 3 & - & - & 1.0 & 34.6 & 47.3 & 17.1 & - & - & 3.0 \\
\hline & 4 & - & - & 7.7 & 25.6 & 34.6 & 28.8 & 3.3 & - & 2.5 \\
\hline & 5 & - & 0.5 & 4.0 & 34.7 & 20.1 & 35.7 & 5.0 & - & 1.9 \\
\hline \multicolumn{11}{|c|}{ Vegetative-semi-mobile biomorph } \\
\hline T. altaicus & 6 & 2.4 & 4.0 & 19.3 & 31.0 & 19.0 & 16.3 & 7.0 & 1.0 & 100.3 \\
\hline T. elegans & 7 & - & 3.8 & 20.6 & 25.4 & 13.7 & 22.8 & 8.4 & 5.3 & 13.1 \\
\hline T. iljinii & 8 & 3.5 & 16.5 & 8.2 & 20.0 & 14.2 & 25.9 & 10.6 & 1.1 & 8.5 \\
\hline \multirow{5}{*}{ T. jenisseensis } & 9 & 1.7 & 7.4 & 23.0 & 35.1 & 17.0 & 10.7 & 5.0 & - & 130.5 \\
\hline & 10 & 1.8 & 5.7 & 24.6 & 30.2 & 17.0 & 5.6 & 14.2 & 0.9 & 10.6 \\
\hline & 11 & - & 3.6 & 16.1 & 28.4 & 7.1 & 9.0 & 32.2 & 3.6 & 14.1 \\
\hline & 12 & - & 2.5 & 11.0 & 15.3 & 8.1 & 22.0 & 33.9 & 7.2 & 15.7 \\
\hline & 13 & 15.6 & 7.8 & 23.4 & 30.9 & 14.9 & 6.5 & 0.6 & 0.3 & 61.6 \\
\hline \multirow{3}{*}{ T. mongolicus } & 14 & 0.3 & 0.8 & 24.2 & 38.8 & 13.9 & 14.7 & 6.5 & 0.8 & 88.3 \\
\hline & 15 & 0.2 & 7.3 & 21.1 & 22.9 & 10.2 & 11.2 & 25.4 & 1.6 & 87.3 \\
\hline & 16 & - & 0.9 & 19.4 & 36.8 & 23.5 & 6.8 & 12.6 & - & 28.3 \\
\hline T. proximus & 17 & - & 15.3 & 10.3 & 23.6 & 5.3 & 23.5 & 18.6 & 3.4 & 20.3 \\
\hline T. sibiricus & 18 & - & 10.2 & 28.6 & 20.4 & 10.2 & 24.5 & 4.1 & 2.0 & 49.3 \\
\hline \multicolumn{11}{|c|}{ Vegetative-mobile biomorph } \\
\hline T. iljinii & 19 & - & 8.0 & 10.4 & 38.6 & 22.2 & 18.4 & 1.9 & 0.5 & 21.2 \\
\hline \multirow{2}{*}{ T. krylovii } & 20 & 10.7 & 20.7 & 8.6 & 10.7 & 6.0 & 28.7 & 12.0 & 2.6 & 15.0 \\
\hline & 21 & 2.3 & 9.9 & 29.4 & 16.8 & 7.2 & 22.5 & 7.9 & 4.0 & 23.3 \\
\hline T. minussinensis & 22 & 1.6 & 8.3 & 6.3 & 21.7 & 7.2 & 29.5 & 21.9 & 3.5 & 114.0 \\
\hline
\end{tabular}

Note: $\mathrm{P}_{\text {ecol }}$ is ecological density.

Coenopopulations 3 and 4 are investigated on deflation plains in sandy steppes, where a large amount of sand is annually winnowed. Together with sand the seeds of $T$. baicalensis are transferred. Solid clusters are formed in separate areas however the outlines of one individual become invisible. Ontogenetic spectra of coenopopulations 1 and 5 differ from the characteristic one. Coenopopulation 1 is studied in the petrophytous steppe on the top of the hill, where the individuals of T. baicalensis do not form solid clusters and are located in the crevices of large stones. Their ontogenetic spectrum of coenopopulation is left-sided with a maximum on individuals of the young generative state.

Lack of substrate and high total projective cover degree $(60 \%)$ leads to the fact that young T. baicalensis individuals develop and remain under the canopy of mature maternal shrub or other species and accumulate in the coenopopulation. The life form of the plant is finally formed till the mature generative state, the features of the life form (all shoots are perennial rosettes, the shrub with above ground root system, small sizes up to $20 \mathrm{~cm}$ ) allow individuals to adapt to conditions at the top of the hills and to survive. In this regard, 
the proportion of individuals of a mature generative state in coenopopulation is also high. The latter indicates that the left-side type of the spectrum is a temporary variant of the centered type.

In coenopopulation 5 a bimodal type of spectrum is set in the sandy steppe, with a predominance of young and old generative states almost equally. Low totalprojective coverage ( $25 \%$ ), free substrate, seed regeneration contribute to the accumulation of individuals of pregenerative state in coenopopulation. In this case the individuals do not form solid clusters, but are situated in such a way that it is possible to determine the boundaries of one individual. The accumulation of individuals of the old generative state indicates the existence of two waves of development of the coenopopulation: emergence of a new population wave before disappearance of the old one.

The species of vegetative-semi-mobile biomorphs (T. altaicus, T. elegans, T. iljinii, T. mongolicus, $T$. proximus, $T$. sibiricus, $T$. jenisseensis) have left-sided type of characteristic ontogenetic spectrum, which is determined by vegetative propagation in the middle of ontogenesis, ramets are rejuvenated for one state, the duration of the young generative state ranges from 1 to 3 years, and the duration of mature generative state $-1-2$ years, self-maintenance of coenopopulations is carried out by seed and vegetative means. Investigation of thirteen coenopopulations showed that they are all normal, most of them are full-membered (Table 3). However, ontogenetic spectra of specific coenopopulations are of three types: left-sided, bimodal and right-sided.

The left-sided type of ontogenetic spectrum with maximum per group of young generative individuals is described in coenopopulations $6,9,10$, 13,14 and 16 . The accumulation of young generative individuals in all coenopopulations is provided by seed and vegetative reproduction. The correlation between individuals of seed and vegetative origin in coenopopulation does not exceed $1: 2$. Coenopopulation 6 is located in the true steppe, where T. altaicus is dominant, projective cover degree of the species is $10 \%$. A high abundance of individuals of undergrowth is noted in the free areas of the substrate and close to the maternal shrubs. Similar behaviour is typical for T. mongolicus in coenopopulation 14 located in the petrophytous steppe. Coenopopulations 9 and $10 \mathrm{~T}$. jenisseensis are investigated along the river banks on a sandy substrate. High humidity of the substrate promotes intensive growth of individuals (diameter of crumbly clone up to $50 \mathrm{~cm}$ ) and seed renewal. Some of the ramets are deeply rejuvenated to the immature state. At the same time, not only the rejuvenated ramets are separated from the maternal shrub, but also the old parts of the shrub that later quickly die.
In coenopopulation 13 located in the highlands on the cobble of the temporary river-bed, $T$. jenisseensis individuals have the vegetative outgrowth and weak propagation (diameter up to $20 \mathrm{~cm}$, the number of partial shrubs in the structure of the individual up to 3 ). The latter occurs rarely and is mainly due to external factors (grazing). The method of self-maintenance of coenopopulation is predominantly seed. With regular seed multiplication and the presence of a free substrate, the correlation between genets and ramets in coenopopulation is $1: 0.1$.

The bimodal ontogenetic spectrum was detected in coenopopulations $7,8,11,15,17,18$. In most coenopopulations the maximum in the spectrum falls on the same ontogenetic groups. The peak in the left part of the spectrum is mainly on the group of young generative individuals and only in coenopopulation 18 it is on the virginile ones, on the right side of the spectrum the peak is formed on the individuals of the old generative state, except coenopopulation 15, where the subsenile individuals predominate. The accumulation of young individuals in coenopopulation is associated with an increase of vegetative reproduction, which begins in the young generative state. The ratio of individuals of seed and vegetative renewal increases and reaches $1: 19$. A low proportion of seed individuals in coenopopulation is connected with irregular seed renewal and low viability of undergrowth in the early stages of ontogeny. Appearing in June, most of them do not survive until August and die. According to our observations, by the end of summer only $2-3$ spouts out of 10 remain. The accumulation of old specimens in most of the coenopopulations is connected with grazing in the habitats of the species under study or with the flexibility of the rocky substrate. This contributes to the mechanical damage to the skeletal axes of the maternal individuals and, as a result, to intensive particulation with the formation of old individuals, the number of which practically coincides with the number of young individuals. In coenopopulation 15 the particulation of adult individuals is enhanced by the winnowing of the sandy substrate, that leads to the exposure of the skeletal axes and their drying out. In coenopopulation $11 \mathrm{~T}$. jenisseensis the absolute maximum of the spectrum falls on a group of subsenile individuals, local - on a group of young generative.

The right-sided ontogenetic spectrum is described in coenopopulation 12, in which the accumulation of individuals of the subsenile state takes place. Stony substrate, the competition of species in the community with a lack of moisture reduces the viability of undergrowth, leads to inhibition of adult thyme individuals and their intensive particulation. The formed ramets are slightly rejuvenated, 
they are in both young and old conditions. Under these conditions, in the majority of individuals ontogenetic polyvariety is found, which is revealed by the reduction of generative period duration or by its omission. Thus, individuals of the virginile ontogenetic state, passing the generative period, proceed into the subsenile state [30].

The characteristic ontogenetic spectrum of coenopopulations in the species of vegetative-mobile biomorph (T. iljinii, T. minussinensis, T. krylovii), as well as in the vegetative-semi-mobile, is leftsided. But accumulation of young individuals in coenopopulation is in a greater degree caused by regular vegetative reproduction, deep rejuvenation of the ramets (to the immature state), predominance of the vegetative method of selfmaintenance of cenopopulation. The ratio of genets and ramets in coenopopulation can reach $1: 42$. Analysis of ontogenetic spectra of coenopopulation 19-22 showed that they are all normal, most of them are full-membered and only in coenopopulation 19 the type of ontogenetic spectrum coincides with the characteristic one. The maximum of spectrum falls on a group of young generative individuals mostly of vegetative origin. However, in coenopopulation 19 along with vegetative reproduction there is also an irregular seed reproduction. Thus, most of the juvenile and immature individuals are of seed origin. They are located near the maternal shrub. In the future, such a neighborhood leads to the inhibition of individuals' undergrowth due to lack of resources and high competition. If there is free substrate some of them persist and undergo complete ontogenesis. In connection with this, individuals of seed origin in the later ontogenetic states in coenopopulation are found very few in number. In coenopopulatons 20-22 accumulation of old generative individuals is typical along with a large number of young individuals. Moreover, in coenopopulations 20 and 22 their strong predomimance is noted. The ontogenetic spectra of these cenopopulations do not coincide with the characteristic one and are bimodal. The formation of the second peak on the right side of the spectrum in coenopopulation 20 is connected with a high total projective coverage of grass stand (up to $90 \%$ ), in coenopopulation 22 - with a high sample plot of the species (up to $25 \%$ ). In both cases young individuals are oppressed and quickly proceed to the old state. Cenopopulation 21 is studied in the herbage and Agropyron repens plant community subjected to periodic anthropogenic impact. In this coenopopulation individuals of seed origin occur very few in number. Regular damage of the skeletal axes increases the vegetative reproduction of individuals, as a result of this, partial formations (partial shoots and shrubs) of different ontogenetic states are separated from the maternal individuals, most of them are the ramets of the virginal ontogenetic state. The absolute maximum of the spectrum falls on the group of individuals of this state. Also a part of the shrub with dying shoots and skeletal axes is quickly separated from the maternal individual in case of mechanical damage. Separated partial shrubs are in the old generative state. The second local maximum in the spectrum provides their accumulation in coenopopulation.

\section{Discussion}

Using many species of plants it has been shown that the type of biomorph and the process of ontogenesis need a wide variety of conditions to remain unchanged [19, 31-34]. Moreover, the authors note that stability of biological features in the species retains the main patterns of ontogenetic structure of their coenopopulations in various habitats, determining the type of characteristic spectrum [23, 35-47]. The type of characteristic ontogenetic spectrum is an important feature of the $\mathrm{CP}$ that points to its stability. Based on the data on structure 22 of the $\mathrm{CP}$ of thyme plants of different biomorphs it has been ascertained that the features, determining the type of characteristic spectrum, are: dominant way of reproduction, period of the onset of vegetative reproduction, the degree of rejuvenation and vital ability of particules, the length of mature generative ontogenetic state. Among the studied CP ontogenetic spectra almost half of them coincide with the typical type. A change in the spectrum of particular CP in the species of the genus Thymus is due to peculiarities of the ecotype and polyvarience of the species' development [30]. Previously it has been reported that polyvarience of the development of the species of the genus Thymus in Siberia is seen in alteration of biomorph within the same species (T. iljinii), in a change of the prevalent method of reproduction and shorten period (or absence) of generative period $[30,38$, 39]. According to L. B. Zaugolnova [23] polyvarience of the development of the individuals of the species leads not only to a change in their biological features and demographic structure of the $\mathrm{CP}$, but also allows us to predict the type of the ontogenetic spectrum, typical of the species.

Based on the study performed and the results obtained earlier [39-41] the features of stable state in the CP are identified in the species of the genus Thymus in the southern Siberia. Characteristic of these features is given in Table 4. It was found that stable states are achieved only in seven CPs $(2-4,6,9,14$, 19), the states of the other CPs tend to be stable. 
Features that affect stability of the coenopopulations in the Thymus species of the different biomorph types

\begin{tabular}{|c|c|c|c|}
\hline \multirow[b]{2}{*}{ Factor } & \multicolumn{3}{|c|}{ The type of biomorph } \\
\hline & $\begin{array}{l}\text { monocentric } \\
(T . \text { baicalensis })\end{array}$ & $\begin{array}{c}\text { implicitly polycentric } \\
\text { (T. altaicus, } T \text {. elegans, } \\
\text { T. iljinii, } T . \text { jenisseensis, } \\
\text { T. mongolicus, } T \text {. proximus, } \\
\text { T. sibiricus })\end{array}$ & $\begin{array}{c}\text { polycentric } \\
\text { (T. krylovii, T. iljinii, } \\
\text { T. minussinensis) }\end{array}$ \\
\hline Substrate mobility & $\begin{array}{l}\text { immobile (mountain top } \\
\text { and slope), mobile } \\
\text { (deflation plain) }\end{array}$ & immobile & mobile \\
\hline $\begin{array}{l}\text { Effect of anthropogenic } \\
\text { factors }\end{array}$ & absent & casual & moderate \\
\hline $\begin{array}{l}\text { The pattern of spatial } \\
\text { distribution } \\
\text { of the individuals } \\
\text { in the CP }\end{array}$ & uniform & uniform & uniform \\
\hline $\begin{array}{l}\text { Vegetative mobility } \\
\text { of the individuals }\end{array}$ & vegetative immobile & vegetative semi-mobile & vegetative mobile \\
\hline $\begin{array}{l}\text { Capacity of the } \\
\text { individuals }\end{array}$ & high & high & high \\
\hline $\begin{array}{l}\text { The way of reproduction } \\
\text { of the CP }\end{array}$ & seed reproduction & $\begin{array}{l}\text { mixed (vegetative and seed } \\
\text { reproduction) }\end{array}$ & $\begin{array}{l}\text { Vegetative } \\
\text { reproduction } \\
\text { is predominant }\end{array}$ \\
\hline CP state & $\begin{array}{l}\text { normal, complete } \\
\text { (a lack of juvenile } \\
\text { and senile individuals } \\
\text { is possible) }\end{array}$ & $\begin{array}{l}\text { normal, complete } \\
\text { (a lack of juvenile } \\
\text { and senile individuals } \\
\text { is possible) }\end{array}$ & $\begin{array}{l}\text { normal, complete } \\
\text { (a lack of juvenile } \\
\text { and senile individuals } \\
\text { is possible) }\end{array}$ \\
\hline $\begin{array}{l}\text { Ecological density } \\
\text { of the } \mathrm{CP}\end{array}$ & $\begin{array}{l}\text { mean values } \\
\text { (cushion-shaped } \\
\text { shrub } \leq 2 \text { individuals } / \mathrm{m}^{2}, \\
\text { shrub } \geq 10 \text { individuals } / \mathrm{m}^{2} \text { ) }\end{array}$ & $\begin{array}{l}\text { mean values } \\
\left(\geq 50 \text { individuals } / \mathrm{m}^{2}\right)\end{array}$ & $\begin{array}{l}\text { mean values } \\
\left(\leq 23 \text { individuals } / \mathrm{m}^{2}\right)\end{array}$ \\
\hline $\begin{array}{l}\text { Type of characteristic } \\
\text { ontogenetic spectrum }\end{array}$ & centered & left-sided (max g1) & $\begin{array}{l}\text { left-sided } \\
\text { (max im, v, g1) }\end{array}$ \\
\hline $\begin{array}{l}\text { Other features for species } \\
\text { of particular biomorph }\end{array}$ & $\begin{array}{l}\text { Boundaries } \\
\text { of the individuals } \\
\text { are not overlapped }\end{array}$ & $\begin{array}{l}\text { Boundaries of the individuals } \\
\text { are partially overlapped }\end{array}$ & $\begin{array}{l}\text { Boundaries } \\
\text { of the individuals } \\
\text { are overlapped }\end{array}$ \\
\hline
\end{tabular}

Most of the studied CPs of monocentric vegetative immobile $T$. baicalensis are in stable state (CP 2-4). Nevertheless, the individuals of the species do not form clusters. In petrophytous steppes they grow in cracks of the big stones, develop under the canopy of mature native shrubs and other species. In sandy steppes the $T$. baicalensis individuals grow so that it is possible to detect their forms.

In the species of implicitly vegetative-semimobile biomorph only $3 \mathrm{CPs}$ are in the stable state (CP 6 - T. altaicus, CP $9-$ T. jenisseensis, CP $14-$ T. mongolicus).Their habitats are associated with steppe plant communities on static substrate, anthropogenic effect (grazing), rock sloughing from the nearest slopes, intensive deflation on tops are possible. Growing on the plain areas, the individuals of the species form continuous clusters (ecological density of coenopopulations reaches 130,5 individuals per $\mathrm{m}^{2}$ ). On the hilltop the individuals grow separately in cracks of the big stones (ecological density of coenopopulations does not exceed
8,5 individuals per $\mathrm{m}^{2}$ ). On the hillslopes, where wind intensity decreases, the presence of fine earth substrate, accumulation of snow cover and moisture in the lower part of the slope, the number of thyme individuals in clusters increases from the top to the foot of the slope (from 4 up to 50 individuals per $\mathrm{m}^{2}$ ). The state of the other $10 \mathrm{CPs}$ (T. elegans, T. iljinii, T. jenisseensis, T. mongolicus, $T$. proximus, $T$. sibiricus) tends to be stable. These coenopopulations are ussually observed on the hilltop and are exposed to regular grazing or under conditions of insufficient moisturizing.

Population behavior of vegetative-mobile species is different. In most habitats, they form continuous clusters. Features that determine stable state of the CP correspond, basically, to the features of stable state of the $\mathrm{CP}$ of vegetative-semimobile species. But due to intensive vegetative propagation and reproduction of the species (up to 90 partial formations are formed in the structure within one mother species) competition between 
them increases, spatial distribution changes leading to alteration in the $\mathrm{CP}$ state. It was found that old individuals were predominant in the $\mathrm{CP}$ when high total projective cover degree was high. Grazing in this case is a favorable factor, since old thyme individuals and other plant species are poached and free parts of substrate appear.

CP 19 of $T$. iljinii located in thyme-feather grass sandy steppe under conditions of moderate grazing reaches stable state. Coenopopulations
20-22 in derivative communities and in steppes with high total projective cover degree TPCD do not reach stable state.

Generalization of the data obtained on biology and the state of cenopopulations of thymes in the South of Siberia enabled us to assign some variants of their population behavior, which could be extrapolated on the other types of species Thymus with similar types of biomorphs (Table 5).

Table 5

A few examples of population behavior of the species of the genus in the southern Siberia

\begin{tabular}{|c|c|c|c|c|}
\hline $\begin{array}{c}\text { Type } \\
\text { of biomorph }\end{array}$ & Specific features of the ecotope & $\begin{array}{l}\text { Specific features } \\
\text { of ontogenesis }\end{array}$ & $\begin{array}{l}\text { Predominant } \\
\text { ontogenetic group } \\
\text { of the individuals }\end{array}$ & $\begin{array}{c}\text { The type } \\
\text { of a spectrum } \\
\text { of the particular } \mathrm{CP}\end{array}$ \\
\hline \multirow{3}{*}{ Monocentric } & $\begin{array}{l}\text { petrophytous steppes of plains } \\
\text { and on the hillslopes }\end{array}$ & $\begin{array}{l}\text { in accord } \\
\text { with the type } \\
\text { of biomorph }\end{array}$ & g2 & $\begin{array}{l}\text { identified as centered } \\
\text { characteristic } \\
\text { ontogenetic spectrum }\end{array}$ \\
\hline & $\begin{array}{l}\text { petrophytous steppes on hill } \\
\text { tops, a lack of substrate }\end{array}$ & $\begin{array}{l}\text { in accord } \\
\text { with the type } \\
\text { of biomorph }\end{array}$ & g1 & $\begin{array}{l}\text { Left-sided (temporary } \\
\text { version) }\end{array}$ \\
\hline & Sandy steppes with low TPCD & $\begin{array}{l}\text { in accord } \\
\text { with the type } \\
\text { of biomorph }\end{array}$ & $\begin{array}{l}\text { individuals of pre- } \\
\text { and post-generative } \\
\text { group }\end{array}$ & $\begin{array}{l}\text { bimodal (two wave } \\
\text { spectra of the } \\
\text { development) }\end{array}$ \\
\hline \multirow{3}{*}{$\begin{array}{l}\text { Implicitly } \\
\text { polycentric }\end{array}$} & $\begin{array}{l}\text { Plain true steppes, high } \\
\text { mountain petrophytous steppes }\end{array}$ & $\begin{array}{l}\text { in accord } \\
\text { with the type } \\
\text { of biomorph }\end{array}$ & g1 & $\begin{array}{l}\text { identified as lef-sided } \\
\text { characteristic } \\
\text { ontogenetic spectrum }\end{array}$ \\
\hline & $\begin{array}{l}\text { Plant communities under } \\
\text { conditions of grazing or moving } \\
\text { stony (sandy) substrate }\end{array}$ & $\begin{array}{l}\text { intensification } \\
\text { of particulation }\end{array}$ & g1 (v) и g3 (ss) & bimodal \\
\hline & $\begin{array}{l}\text { mountain petrophytous steppes, } \\
\text { a deficiency of the substrate } \\
\text { and high TPCD }\end{array}$ & $\begin{array}{l}\text { reduction } \\
\text { in duration } \\
\text { (or jump) } \\
\text { generative period }\end{array}$ & ss & right-sided \\
\hline \multirow{3}{*}{$\begin{array}{l}\text { Explicitly } \\
\text { polycentric }\end{array}$} & Plain sandy steppe & $\begin{array}{l}\text { in accord } \\
\text { with the type } \\
\text { of biomorph }\end{array}$ & g1 & $\begin{array}{l}\text { identified as lef-sided } \\
\text { characteristic } \\
\text { ontogenetic spectrum }\end{array}$ \\
\hline & $\begin{array}{l}\text { mountain petrophytous steppes } \\
\text { and plain sandy steppes } \\
\text { with high TPCD or PC }\end{array}$ & $\begin{array}{l}\text { reduction } \\
\text { in duration } \\
\text { (or jump) } \\
\text { generative period }\end{array}$ & g1 and g3 & bimodal \\
\hline & $\begin{array}{l}\text { Plant communities under } \\
\text { anthropogenic effect }\end{array}$ & $\begin{array}{l}\text { intensification } \\
\text { of particulation }\end{array}$ & $\mathrm{v}$ and $\mathrm{g} 3$ & bimodal \\
\hline
\end{tabular}

The results obtained confirm the statement of E. E. Gogina [9] that due to dissemination and reclamation of the areas with wide spectrum of habitat Thymus plants obtained new plasticity and created the mechanisms of adaptation both at organism and population levels: change of vital form, vegetative mobility and reproduction, polyvarience of ontogeny, high ecological density, increase of survival ability of young individuals due to overgrazing of the old ones.

\section{Conclusions}

In the southern Siberia the species of the genus Thymus showed a variety of the types of bio- morphs (monocentric vegetative-immobile, implicitly polycentric vegetative-semi-mobile, explicitly polycentric vegetative-mobile) and ontogenesis. It has been determined that implicitly vegetativesemi-mobile biomorph is formed in most species. Biological specific features of implicitly vegetative-semi-mobile and explicitly polycentric vegetative-mobile types of biomorphs (vegetative propagation, rejuvenation of ramets, self-maintenance of coenopopulation with the seed and vegetative ways) identify the left-sided type of the characteristic spectrum, of monocentric (long mature generative state of the species; only seed way of reproduction) - the centered one. Among 10 types studied only in 7 coenopopulations from 22 the type of ontogenetic spectrum coincides with 
the characteristic one. The difference between ontogenetic spectra of the most studied coenopopulations from the characteristic type is associated with polyvarience of the individual development and peculiarities of the ecotype.

For thyme plants of various biomorphs we have defined environmental factors of the habitats (mobility of the substrate, grazing) and the features (spatial distribution of the individuals in the $\mathrm{CP}$, vegetative mobility and capacity of the individuals, the way of self-maintenance in the $\mathrm{CP}$, the state of the $\mathrm{CP}$, ecological density of the $\mathrm{CP}$, the type of characteristic ontogenetic spectrum) that affect stable state of the CP. On the basis of the above, it has been ascertained that most of the studied CPs in the territory of the southern Siberia do not reach stable state. A comparative analysis of the data obtained allowed us to give a few examples of the population behavior which could be extrapolated on the other types of the species Thymus with similar types of biomorphs.

\section{Библиографический список}

1. Walker, B. Conserving Biological Diversity through Ecosystem Resilience / B. Walker // Conservation Biology. 1995. - Vol. 9(4). - P. 747-752. DOI: 10.1046/j.1523-1739.1995.09040747.x.

2. Смирнова, О. В. Популяционная организация биоценотического покрова лесных ландшафтов / О. В. Смирнова // Успехи современной биологии. - 1998. - № 2. - С. 148-165.

3. Guisan, A. Predictive habitat distribution models in ecology / A. Guisan, N. E. Zimmermann // Ecological Modelling. - 2000. - Vol. 135(2). - P. 147-186.

4. Gamfeldt, L. Multiple functions increase the importance of biodiversity for overall ecosystem functioning / L. Gamfeldt, H. Hillebrand, P. R. Jonsson // Ecology. - 2008. - Vol. 89(5). - P. 1223-1231.

5. Смирнова, О. В. Потенциальная растительность и потенциальный экосистемный покров / О. В. Смирнова, Н. А. Торопова // Успехи современной биологии. - 2016. - Т. 136(2). - С. 199-211.

6. Коротков, В. Н. Основные концепции и методы восстановления природных лесов Восточной Европы / В. Н. Коротков // Russian Journal of Ecosystem Ecology. - 2017. - Vol. 2 (1). - P. 1-18.

7. Оценка и сохранение биоразнообразия лесного покрова в заповедниках Европейской России / под ред. Л. Б. Заугольновой, Т. Ю. Браславской. - М. : Научный мир, 2000. - 185 с.

8. Смирнова, О. В. Основные понятия экологии экосистем с позиции популяционной парадигмы / О.В.Смирнова // Принципы и способы сохранения биоразнообразия : сб. ст. IV Всерос. науч. конф. с междунар. уч. Йошкар-Ола : Мар. гос. ун-т, 2010. - С. 46-48.

9. Гогина, Е. Е. Изменчивость и формообразование в роде тимьян / Е. Е. Гогина. - М. : Наука, 1990. - 208 с.

10. Огуреева, Г. Н. Ценотическое разнообразие Дауро-Монгольских степей в связи с ландшафтной структурой территории и хозяйственным использованием / Г. Н. Огуреева, И. М. Микляева, В. А. Снытко // Степи Северной Евразии. - Оренбург : ИПК «Газпромпечать», 2009. - С. 501-504.

11. Пешкова, Г. А. Растительность Сибири (Предбайкалье и Забайкалье) / Г. А. Пешкова. - Новосибирск : Наука, 1985. - 144 c.

12. Касьянова, Л. Н. Растительность современных эоловых образований на острове Ольхон (озеро Байкал) / Л. Н. Касьянова, М. Г. Азовский // Известия Самарского научного центра РАН. - 2009. - Т. 11(4). C. $630-637$.

13. Самдан, А. М. Флора и растительность песчаных ландшафтов Тувы / А. М. Самдан, С. С. Курбатская // Отечественная геоботаника: основные вехи и перспективы. - СПб., 2011. - Т. 1. - С. 225-227.

14. Самбуу, А. Д. Динамика видового состава в восстанавливающихся сухих степях Тувы / А. Д. Самбуу // Горные экосистемы Южной Сибири: изучение, охрана и рациональное природопользование. - Барнаул, 2005. - Вып. 1. - С. 243-246.

15. Худоногова, Е. Г. Эколого-фитоценотические особенности Thymus asiaticus Serg. и T. baicalensis Serg. в Предбайкалье / Е. Г. Худоногова, Т. В. Киселева, Н. Ю. Черниговская, Н. А. Николаева // Вестник Алтайского государственного аграрного университета. - 2013. - № 3 (101). - С. 58-62.

16. Ревушкин, А. С. Высокогорная флора Алтая / А. С. Ревушкин / под ред. А. В. Положий. - Томск : Изд-во Томского университета, 1988. - $320 \mathrm{c}$.

17. Доронькин, В. М. 27. Thymus L. - тимьян, богородская трава / В. М. Доронькин // Флора Сибири. Pyrolaceae-Lamiaceae (Labiatae). - Новосибирск : Наука, 1997. - Т. 11. - С. 205-220.

18. Серебряков, И. Г. Экологическая морфология растений / И. Г. Серебряков. - М. : Наука, 1962. - 378 с.

19. Смирнова, О. В. Структура травяного покрова широколиственных лесов / О. В. Смирнова. - М. : Наука, 1987. $-208 \mathrm{c}$.

20. Работнов, Т. А. Жизненный цикл многолетних травянистых растений в луговых ценозах / Т. А. Работнов // Тр. БИН АН СССР; Сер. 3: Геоботаника. - 1950. - Вып. 6. - С. 7-204.

21. Уранов, А. А. Возрастной спектр фитоценопопуляций как функция времени и энергетических волновых процессов / А. А. Уранов // Биологические науки. - 1975. - № 2. - С. 7-34.

22. Смирнова, О. В. Ценопопуляции растений: основные понятия и структура / О. В. Смирнова, Л. Б. Заугольнова, Н. А. Торопова. - М. : Наука, 1976. - 217 с. 
23. Заугольнова, Л. Б. Структура популяций семенных растений и проблемы их мониторинга : автореф. дис. ... д-ра биол. наук / Заугольнова Л. Б. - СПб., 1994. - 70 с.

24. Одум, Ю. Экология / Ю. Одум. - М. : Мир, 1986. - Т. 2. - 209 с.

25. Talovskaya (Kolegova), E. B. Thymus baicalensis (Lamiaceae) morphological transformation under different environmental conditions / E. B. Talovskaya (Kolegova) // Contemporary Problems of Ecology. - 2015. - Vol. 8 (5). P. 607-613.

26. Черемушкина, В. А. Онтогенез подушковидной жизненной формы Thymus baicalensis (Lamiaceae) / В. А. Черемушкина, Е. Б. Колегова // Ботанический журнал. - 2014. - Т. 99(10). - С. 1109-1118.

27. Жукова, Л. А. Популяционная жизнь растений / Л. А. Жукова. - Йошкар-Ола : РИИК «Ланар», 1995. $224 \mathrm{c}$.

28. Черемушкина, В. А. Онтогенез колюрии гравилатовидной (Coluria geoides (Pall.) Ledeb.) / В. А. Черемушкина, Т. В. Леонова // Онтогенетический атлас растений: научное издание. - Йошкар-Ола, 2011. - T. VI. C. $164-170$.

29. Колегова, Е. Б. Онтоморфогенез вегетативно подвижных кустарничков из рода Thymus L. (Lamiaceae) в Хакасии / Е. Б. Колегова, В. А. Черемушкина // Бюллетень Московского общества испытателей природы. Отдел биологический. - 2013. - Т. 118 (2). - С. 70-76.

30. Колегова, Е. Б. Онтогенез видов рода Thymus L. (Lamiaceae) и структура их ценопопуляций в Хакасии / Е. Б. Колегова, В. А. Черемушкина // Современные проблемы популяционной экологии, геоботаники, систематики и флористики : сб. ст. междунар. науч. конф., посвящ. 110-летию А. А. Уранова. - Кострома : КГУ им. Н. А. Некрасова, 2011. - Т. 1. - С. 129-133.

31. Воронцова, Л. И. Ценопопуляции типчака (Festuca sulcata Hack.) и белой полыни (Artemisia Cerheana Web.) в южной полупустыне Западного Прикаспия : автореф. дис. ... канд. биол. наук / Воронцова Л. И. M., 1971. - 15 c.

32. Заугольнова, Л. Б. Связь возрастного спектра ценопопуляций с биологическими свойствами вида (на примере Acantholimon diapensioides Bge) / Л. Б. Заугольнова // Возрастной состав популяций цветковых растений в связи с их онтогенезом. - М., 1974. - С. 38-55.

33. Черемушкина, В. А. Связь возрастного состава ценопопуляций с ходом онтоморфогенеза (на примере корневищных луков и копеечников) / В. А. Черемушкина, Н. А. Попова // Популяционная экология растений. M., 1987. - C. 105-111.

34. Evstigneev, O. I. Ontogenetic stages of trees: an overview / O. I. Evstigneev, V. N. Korotkov // Russian Journal of Ecosystem Ecology. - 2016. - Vol. 1(2). - P. 1-31. DOI: 10.21685/2500-0578-2016-2-1.

35. Восточноевропейские широколиственные леса / под ред. О. В. Смирновой. - М. : Наука, 1994. - 364 с.

36. Черемушкина, В. А. О характерном и видовом онтогенетических спектрах ценопопуляций растений разных жизненных форм / В. А. Черемушкина // Принципы и способы сохранения биоразнообразия : сб. ст. III Всерос. науч. конф. - Йошкар-Ола ; Пущино : МарГУ, 2008. - С. 39-40.

37. Злобин, Ю. А. Популяции редких видов растений: теоретические основы и методика изучения / Ю. А. Злобин, В. Г. Скляр, А. А. Клименко. - Сумы : Университетская книга, 2013. - 439 с.

38. Колегова, Е. Б. Жизненные формы видов рода Thymus L. в Республике Хакасия / Е. Б. Колегова // Растительный мир и его охрана : сб. ст. Междунар. науч. конф., посвящ. 80-летию Института ботаники и фитоинтродукции. - Алматы : LEM, 2012. - С. 380-381.

39. Kolegova, E. B. Ontogenetic structure and assessment of state of Thymus mongolicus (Lamiaceae) coenopopulations in Southern Siberia / E. B. Kolegova, V. A. Cheryomushkina // Contemporary Problems of Ecology. - 2015. Vol. 8(2). - P. 155-161.

40. Колегова, Е. Б. Онтогенетическая структура ценопопуляций Thymus jenisseensis (Lamiaceae) на юге Сибири / Е. Б. Колегова, В. А. Черемушкина // Растительные ресурсы. - 2015. - Вып. 1. - С. 60-69.

41. Таловская (Колегова), Е. Б. Онтогенетическая структура ценопопуляций Thymus baicalensis (Lamiaceae) на юге Сибири / Е. Б. Колегова // Вестник Томского государственного университета. Биология. - 2016. № 1 (33). - С. 39-49.

\section{References}

1. Walker B. Conservation Biology. 1995, vol. 9 (4). pp. 747-752. DOI: 10.1046/j.1523-1739.1995.09040747.x.

2. Smirnova O. V. Uspekhi sovremennoy biologii [Achievements of modern biology]. 1998, no. 2, pp. $148-165$.

3. Guisan A.,. Zimmermann N. E. Ecological Modelling. 2000, vol. 135 (2), pp. 147-186.

4. Gamfeldt L., Hillebrand H., Jonsson P. R. Ecology. 2008, vol. 89 (5), pp. 1223-1231.

5. Smirnova O. V., Toropova N. A. Uspekhi sovremennoy biologii [Achievements of modern biology]. 2016 , vol. 136 (2), pp. 199-211.

6. Korotkov V. N. Russian Journal of Ecosystem Ecology. 2017, vol. 2 (1), pp. 1-18.

7. Otsenka i sokhranenie bioraznoobraziya lesnogo pokrova v zapovednikakh Evropeyskoy Rossii [Assessment and preservation of biodiversity of forest cover in European Russian nature reserves]. Eds. L. B. Zaugol'nova, T. Yu. Braslavskaya. Moscow: Nauchnyy mir, 2000, 185 p.

8. Smirnova O. V. Printsipy i sposoby sokhraneniya bioraznoobraziya: sb. st. IV Vseros. nauch. konf. s mezhdunar. $u c h$. [Principles and methods of preserving biodiversity: proceedings of IV National scientific conference with international participation]. Yoshkar-Ola: Mar. gos. un-t, 2010, pp. 46-48. 
9. Gogina E. E. Izmenchivost' i formoobrazovanie v rode tim'yan [Changeability and morphogeny in genus Thymus]. Moscow: Nauka, 1990, 208 p.

10. Ogureeva G. N., Miklyaeva I. M., Snytko V. A. Stepi Severnoy Evrazii [Steppes of northern Eurasia]. Orenburg: IPK «Gazprompechat'», 2009, pp. 501-504.

11. Peshkova G. A. Rastitel'nost' Sibiri (Predbaykal'e i Zabaykal'e) [Siberian vegetation (Cisbaikalia and Transbaikalia)]. Novosibirsk: Nauka, 1985, 144 p.

12. Kas'yanova L. N., Azovskiy M. G. Izvestiya Samarskogo nauchnogo tsentra RAN [Proceedings of Samara research centre of RAS]. 2009, vol. 11 (4), pp. 630-637.

13. Samdan A. M., Kurbatskaya S. S. Otechestvennaya geobotanika: osnovnye vekhi i perspektivy [National geobotany: main stages and perspectives]. Saint-Petersburg, 2011, vol. 1, pp. 225-227.

14. Sambuu A. D. Gornye ekosistemy Yuzhnoy Sibiri: izuchenie, okhrana i ratsional'noe prirodopol'zovanie [Modern ecosystems of Southern Siberia: studies, preservation and rational nature management]. Barnaul, 2005, iss. 1, pp. 243-246.

15. Khudonogova E. G., Kiseleva T. V., Chernigovskaya N. Yu., Nikolaeva N. A. Vestnik Altayskogo gosudarstvennogo agrarnogo universiteta [Proceedings of Altai State Agrarian University]. 2013, no. 3 (101), pp. 58-62.

16. Revushkin A. S. Vysokogornaya flora Altaya [Highland flora of Altai]. Tomsk: Izd-vo Tomskogo universiteta, $1988,320 \mathrm{p}$

17. Doron'kin V. M. Flora Sibiri. Pyrolace-ae-Lamiaceae (Labiatae) [Siberian flora. Pyrolace-ae-Lamiaceae (Labiatae)]. Novosibirsk: Nauka, 1997, vol. 11, pp. 205-220.

18. Serebryakov I. G. Ekologicheskaya morfologiya rasteniy [Ecological plant morphology]. Moscow: Nauka, 1962, $378 \mathrm{p}$.

19. Smirnova O. V. Struktura travyanogo pokrova shirokolistvennykh lesov [Structure of grass cover of broad-leaved forests]. Moscow: Nauka, 1987, 208 p.

20. Rabotnov T. A. Tr. BIN AN SSSR; Ser. 3: Geobotanika [Proceedings of AS USSR: series 3: Geobotany]. 1950, iss. 6, pp. 7-204.

21. Uranov A. A. Biologicheskie nauki [Biological sciences]. 1975, no. 2, pp. 7-34.

22. Smirnova O. V., Zaugol'nova L. B., Toropova N. A. Tsenopopulyatsii rasteniy: osnovnye ponyatiya i struktura [Cenopopulations of plants: main concepts and structure]. Moscow: Nauka, 1976, 217 p.

23. Zaugol'nova L. B. Struktura populyatsiy semennykh rasteniy i problemy ikh monitoringa: avtoref. dis. d-ra biol. nauk [Population structure of seed plants and problems of their monitoring: abstract of thesis of Doctor of Biological Sciences]. Saint-Petersburg., 1994, 70 p.

24. Odum Yu. Ekologiya [Ecology]. Moscow: Mir, 1986, vol. 2, 209 p.

25. Talovskaya (Kolegova) E. B. Contemporary Problems of Ecology. 2015, vol. 8 (5), pp. 607-613.

26. Cheryomushkina V. A., Kolegova E. B. Botanicheskiy zhurnal [Botanical journal]. 2014, vol. 99 (10), pp. 1109_ 1118.

27. Zhukova L. A. Populyatsionnaya zhizn' rasteniy [Population life of plants]. Yoshkar-Ola: RIIK «Lanar», 1995, $224 \mathrm{p}$.

28. Cheryomushkina V. A., Leonova T. V. Ontogeneticheskiy atlas rasteniy: nauchnoe izdanie [Ontogenetic plant atlas: scientific edition]. Yoshkar-Ola, 2011, vol. VI, pp. 164-170.

29. Kolegova E. B., Cheryomushkina V. A. Byulleten' Moskovskogo obshchestva ispytateley prirody. Otdel biologicheskiy [Proceedings of Moscow Society of Naturalists. Biological Series]. 2013, vol. 118 (2), pp. 70-76.

30. Kolegova E. B., Cheryomushkina V. A. Sovremennye problemy populyatsionnoy ekologii, geobotaniki, sistematiki i floristiki: sb. st. mezhdunar. nauch. konf., posvyashch. 110-letiyu A. A. Uranova [Modern issues of populational ecology, geobotany, systematics and floristry: proceedings of international scientific conference dedicated to 110 th anniversary of A.A. Uranov]. Kostroma: KGU im. N. A. Nekrasova, 2011, vol. 1, pp. 129-133.

31. Vorontsova L. I. Tsenopopulyatsii tipchaka (Festuca sulcata Hack.) i beloy polyni (Artemisia Cerheana Web.) $v$ yuzhnoy polupustyne Zapadnogo Prikaspiya: avtoref. dis. kand. biol. nauk [Cenopopulation of sheep fescue and white sage in southern half desert of Western Caspian Sea Region: abstrack of candidate of biological sciences]. Moscow, 1971, 15 p.

32. Zaugol'nova L. B. Vozrastnoy sostav populyatsiy tsvetkovykh rasteniy $v$ svyazi s ikh ontogenezom [Age composition of flowery plant population due to their ontogenesis]. Moscow, 1974, pp. 38-55.

33. Cheryomushkina V. A., Popova N. A. Populyatsionnaya ekologiya rasteniy [Populational plant ecology]. Moscow, 1987, pp. 105-111.

34. Evstigneev O. I., Korotkov V. N. Russian Journal of Ecosystem Ecology. 2016, vol. 1 (2), pp. 1-31. DOI: 10.21685/2500-0578-2016-2-1.

35. Vostochnoevropeyskie shirokolistvennye lesa [East European broad-leaved forests]. Ed. by O. V. Smirnova. Moscow: Nauka, 1994, 364 p.

36. Cheryomushkina V. A. Printsipy i sposoby sokhraneniya bioraznoobraziya: sb. st. III Vseros. nauch. konf. [Principles and methods of preserving biodiversity: proceedings of III National scientific conference]. Yoshkar-Ola; Pushchino: MarGU, 2008, pp. 39-40.

37. Zlobin Yu. A., Sklyar V. G., Klimenko A. A. Populyatsii redkikh vidov rasteniy: teoreticheskie osnovy $i$ metodika izucheniya [Populations of rare plant species: theoretical principles and methods of studies]. Sumy: Universitetskaya kniga, 2013, 439 p. 
38. Kolegova E. B. Rastitel'nyy mir i ego okhrana: sb. st. Mezhdunar. nauch. konf., posvyashch. 80-letiyu Instituta botaniki i fito-introduktsii [Plant world and its preservation: proceedings of International scientific conference dedicated to $80^{\text {th }}$ anniversary of Institution of botany and phyto-introduction]. Almaty: LEM, 2012, pp. 380-381.

39. Kolegova E. B., Cheryomushkina V. A. Contemporary Problems of Ecology. 2015, vol. 8 (2), pp. $155-161$.

40. Kolegova E. B., Cheryomushkina V. A. Rastitel'nye resursy [Plant resources]. 2015, iss. 1, pp. 60-69.

41. Talovskaya (Kolegova) E. B. Vestnik Tomskogo gosudarstvennogo universiteta. Biologiya [Proceedings of Tomsk State University. Biology]. 2016, no. 1 (33), pp. 39-49. 